\title{
Sexuality and other issues in Africa and beyond
}

EIC, African Health Sciences.

\author{
James K Tumwine
}

DOI: https://dx.doi.org/10.4314/ahs.v18i2.1

Cite as: Tumwine JK. Sexuality and other issues in Africa and beyond. Afri Health Sci. 2018;18(2):i-iii. https://dx.doi.org/10.4314/abs. $v 18 i 2.1$

Welcome to this June 2018 issue of African Health Sciences. It focusses on sexuality, non-communicable diseases, HIV, child health and other challenges besetting the health systems in low and middle income countries in Africa and other environs.

Now to sexuality: Researchers from Nigeria report on the burden and pattern of child sexual abuse among adolescents. They found a $25 \%$ prevalence among adolescents studied. Most perpetrators were boyfriends or neighbours, and only a third of the cases reported the abuse. ${ }^{1}$

Kenyan researchers on the other hand ${ }^{2}$ report on sexual experiences of 200 secondary school students in Nakuru, where a large number had had sexual experiences. The work by Adimora $^{3}$ and others, on the other hand, brings to the fore the predictive power of the home environment and peer pressure on disruptive and risky sexual behaviour of adolescents.

Now to sexuality of pregnancy: Iranian authors assessed effects of pregnancy on sexual function of couples. They report that sexual dysfunction is a widespread problem during pregnancy among Iranian couples. This paper makes very interesting reading and it is highly recommended. ${ }^{4}$

Togolese scientists studied the effect of leaves of S.mombin on uterine muscle contraction in child birth. ${ }^{5}$ They concluded that the hydro-ethanolic extract of S.mombin leaves exert their effect through prostaglandins release, $\alpha 2$-adrenoreceptors stimulation and calcium release, and subsequent uterine smooth muscle contraction.

The next paper ${ }^{6}$ by Kumuda and others reports on salivary cortisol levels in postmenopausal women with psy- chosomatic disorders. They found that salivary cortisol was higher in post-menopausal women with clinically diagnosed psychosomatic disorders, than in those without. To conclude this sexuality section, we bring you the seminal work by Stella Gbotoloru who found that quinine blocks ovulation and induces oxidative stress in the ovary. $^{7}$

\section{Non Communicable Diseases}

In the next section, we bring you very interesting papers on non-communicable diseases. Shen and others have developed a cytokine signature from peripheral blood that serves as a fingerprint for hepatocellular carcinoma diagnosis. ${ }^{8}$ Chinese authors have demonstrated that ' $572 \mathrm{G} / \mathrm{C}$ polymorphism of the IL-6 gene may be a risk factor for the development of prostate cancer in Asians."

On the other hand, a study from South Africa casts doubt on the 'yield of interpretable test result of fine needle aspiration cytology when compared to breast ultrasonography', prompting them to recommend omission of FNAC from the triple assessment of women with suspected breast cancer. ${ }^{10}$ The work by Jibrin and others ${ }^{11}$ highlights the histo-pathological pattern of brain tumours in Nigeria. The rest of the NCD papers, deal with diagnosis of ischemic disease ${ }^{12}$, rheumatoid arthritis ${ }^{13}$, the retina ${ }^{14}$, hearing $\operatorname{loss}^{15}$, limb injury ${ }^{16}$, poisoning ${ }^{17}$, and glaucoma. ${ }^{18}$

\section{Child Health}

We have a few papers on child health. South African clinicians bring us an interesting paper on congenital abnormalities found during circumcision. ${ }^{19}$ Oral mutilation of infants has been reported in East Africa, but no substantial work had been reported from the Sudan. We bring you an interesting treatise on this subject by Elgamri and 
others. ${ }^{20}$ They found that $10 \%$ of the children studied had infant oral mutilation and identified several associated factors.

The other papers are on neonatal mortality in Ghana ${ }^{21}$, and new born thyroid function. ${ }^{22}$

\section{Infections:}

HIV of course is the big story here, with authors reporting adherence to $\mathrm{ART}^{23}$, physical activity ${ }^{24}$ and disputes over HIV diagnosis by ELISA ${ }^{25}$, hepatitis $\mathrm{C}^{26}$ and surveillance of epidemic prone diseases. ${ }^{27}$

Finally, we bring you papers on uroliths ${ }^{28}$, kidney disease $^{29}$, childhood cervical spine injuries ${ }^{30}$, and several letters to the editor in response to previous publications on oesophageal candidiasis. ${ }^{31,32}$

So relax and enjoy this exotic menu of papers in African Health Sciences.

\section{James K Tumwine}

Editor in Chief, African Health Sciences.

\section{References}

1. David N, Ezechi O, Wapmuk A, Gbajabiamila T, Ohihoin A, Herbertson E, Odeyemi K. Child sexual abuse and disclosure in South Western Nigeria: a community based study. Afri Health Sci. 2018;18(2): 199-208. https:// dx.doi.org/10.4314/ahs.v18i2.2

2. Esho T, Datta A, Muniu S. Sexuality experiences of secondary school students in Nakuru, Kenya: a cross-sectional study. Afri Health Sci. 2018;18(2): 209-217. https:// dx.doi.org/10.4314/ahs.v18i2.3

3. Adimora DE, Akaneme IN, Aye EN. Peer pressure and home environment as predictors of disruptive and risky sexual behaviours of secondary school adolescents. Afri Health Sci. 2018;18(2): 218-226. https://dx.doi. org/10.4314/ahs.v18i2.4

4. Khalesi ZB, Bokaie M, Attari SM. Effect of pregnancy on sexual function of couples. Afri Health Sci. 2018;18(2): 227-234. https://dx.doi.org/10.4314/ahs.v18i2.5

5. Pakoussi T, Mouzou AP, Metowogo K, Aklikokou KA, Gbeassor M. How do Spondias mombin L (Anacardiaceae) leaves extract increase uterine smooth muscle contractions to facilitate child birth in parturient women? Afri Health Sci. 2018;18(2): 235-243. https://dx.doi.org/10.4314/ ahs.v18i2.6
6. Kumuda R, Suchetha K, Subhas GB, Urvashi AS, Harshini U. Estimation of salivary cortisol level in post-menopausal women with Psychosomatic disorders. Afri Health Sci. 2018;18(2): 244-252. https:/ /dx.doi. org/10.4314/ahs.v18i2.7

7. Gbotolorun SC, Inikori O, Bamisi OD, Osinubi AAA, Okanlawon AO. Quinine inhibits ovulation and produces oxidative stress in the ovary of cyclic Sprague-Dawley rats. Afri Health Sci. 2018;18(2): 253-259. https://dx.doi. org/10.4314/ahs.v18i2.8

8. Shen J, Wu H, Peng N, Cai J. An eight cytokine signature identified from peripheral blood serves as a fingerprint for hepatocellular cancer diagnosis. Afri Health Sci. 2018;18(2): 260-266. https://dx.doi.org/10.4314/ahs. v18i2.9

9. Wang Y, Chen X, Chen Y. Interleukin-6 gene -572G/C polymorphism and prostate cancer risk. Afri Health Sci. 2018;18(2): 267-272. https://dx.doi.org/10.4314/ahs. v18i2.10

10. Pillay S, Cheddie S, Moodley Y. Fibroadenoma of the breast in a South African population -a pilot study of the diagnostic accuracy of fine needle aspirate cytology and breast ultrasonography. Afri Health Sci. 2018;18(2): 273280. https://dx.doi.org/10.4314/ahs.v18i2.11

11. Jibrin P, Ibebuike K, Ado-wanka AN. Histo-pathological pattern of intracranial tumours in National Hospital, Abuja. Afri Health Sci. 2018;18(2): 281-286. https://dx. doi.org/10.4314/ahs.v18i2.12

12. Alkireidmi MA, Al-Abbasi FA, Mehanna MG, Moselhy SS. Biochemical markers as diagnostic/prognostic indicators for ischemic disease. Afri Health Sci. 2018;18(2): 287-294. https://dx.doi.org/10.4314/ahs.v18i2.13

13. Meyer P, Ally M, Hodkinson B, Anderson R, Tikly M. Diagnostic utility of, and influence of tobacco usage and genetic predisposition on, immunoglobulin $\mathrm{A}$, rheumatoid factor and anti-citrullinated peptide auto-antibodies in South African rheumatoid arthritis patients. Afri Health Sci. 2018;18(2): 295-303. https://dx.doi.org/10.4314/ ahs.v18i2.14

14. Rampersad N, Hansraj R. Repeatability and reproducibility of retinal nerve fibre layer thickness measurements with the iVue-100 optical coherence tomographer. Afri Health Sci. 2018;18(2): 304-312. https://dx.doi. org/10.4314/ahs.v18i2.15

15. Louw C, Swanepoel D-W,Eikelboom RH, Hugo J. Prevalence of hearing loss at primary health care clin- 
ics in South Africa. Afri Health Sci. 2018;18(2): 313- 320. https://dx.doi.org/10.4314/ahs.v18i2.16

16. Ammori MB, Abu-Zidan FM. The biomechanics of lower limb injuries in frontal-impact road traffic collisions. Afri Health Sci. 2018;18(2): 321-332. https://dx.doi. org/10.4314/ahs.v18i2.17

17. Yuan H, Yuan M, Tang Y, Wang B, Zhan X. MicroRNA expression profiling in human acute organophosphorus poisoning and functional analysis of dysregulated miRNAs. Afri Health Sci. 2018;18(2): 333-342. https:// dx.doi.org/10.4314/ahs.v18i2.18

18. Omatiga AG, Onakpoya OH, Idowu BM, Asaleye CM, Adegbehingbe BO, Aderibigbe AS. B-mode sonographic evaluation of optic nerve sheath diameter and lens thickness in Nigerian adults with glaucoma. Afri Health Sci. 2018;18(2): 343-351. https://dx.doi.org/10.4314/ahs. v18i2.19

19. Spencer K, Mokhele I, Firnhaber C. Congenital genital abnormalities detected during routine circumcision at a South African institution: a retrospective record review. Afri Health Sci. 2018;18(2): 352-358. https://dx.doi. org/10.4314/ahs.v18i2.20

20. Elgamri AI, Ahmed AT, Haj-Siddig OE, Chin JR. Infant oral mutilation (IOM) related to traditional practices among inner city pre-school children in Sudan. Afri Health Sci. 2018;18(2): 359-368. https://dx.doi.org/10.4314/ ahs.v18i2.21

21. Owusu BA, Lim A, Makaje N, Wobil P, SameAe A. Neonatal mortality at the neonatal unit: the situation at a teaching hospital in Ghana. Afri Health Sci. 2018;18(2): 369-377. https://dx.doi.org/10.4314/ahs.v18i2.22

22. Korkmaz G, Özçetin M, Çă̆ Y, Yükselmiş U, Öngel V, Issık O. Thyroid function in healthy and unhealthy preterm newborns. Afri Health Sci. 2018;18(2): 378-383. https://dx.doi.org/10.4314/ahs.v18i2.23

23. Motazedian N, Sayadi M, Firoozbakhtian A. Non- adherence to anti-retroviral medication in Shiraz, 2014: a cross sectional study. Afri Health Sci. 2018;18(2): 384-393. https://dx.doi.org/10.4314/ahs.v18i2.24

24. Vancampfort D, Stubbs B, Mugisha J. Physical activity and HIV in sub-Saharan Africa: a systematic review of correlates and levels. Afri Health Sci. 2018;18(2): 394-406. https://dx.doi.org/10.4314/ahs.v18i2.25

25. Yuksel P, Saribas S, Kuskucu M, Mutcali SI, Kosan E, Habip Z, Demirci M, Kara ES, Birinci I, Caliskan R, Dinc HO, Midilli K, Ziver T, Kocazeybek B. Problems encountered in conventional HIV 1/2 Algorithms: lack of necessity for immunoblot assays to confirm repeated ELISA reactive results. Afri Health Sci. 2018;18(2): 407416. https://dx.doi.org/10.4314/ahs.v18i2.26

26. Abd El-Kader SM, Al-Jiffri OH. Impact of weight reduction on selected immune system response among Hepatitis C virus Saudi patients. Afri Health Sci. 2018;18(2): 417-427. https://dx.doi.org/10.4314/ahs.v18i2.27

27. Dairo MD, Afolayan DO, Akinyemi JO. Compliance with epidemic-prone diseases surveillance and response guidelines among health officers at surveillance units in South-West Nigeria. Afri Health Sci. 2018;18(2): 428-436. https://dx.doi.org/10.4314/ahs.v18i2.28

28. Meka IA, Ugonabo MC, Ebede SO, Agbo EO. Composition of uroliths in a tertiary hospital in SouthEast Nigeria. Afri Health Sci. 2018;18(2): 437-445. https://dx.doi. org/10.4314/ahs.v18i2.29

29. Gimba ZM, Abene EE, Agbaji OOO, Agaba EI. Secondary hyperparathyroidism among Nigerians with chronic kidney disease. Afri Health Sci. 2018;18(2): 446457. https://dx.doi.org/10.4314/ahs.v18i2.30

30. Ibebuike K, Roussot M, Watt J, Dunn R. Management challenges of traumatic spondylolisthesis of the Axis with an unusual C2-C3 posterior subluxation in a paediatric patient: case report and literature review. Afri Health Sci. 2018;18(2): 458-467. https://dx.doi.org/10.4314/ ahs.v18i2.31

31. Bongomin F, Fayemiwo SA. Letter to the editor 1: Predictors of oesophageal candidiasis in persons with or without HIV infection. Afri Health Sci. 2018;18(2): 468469. https://dx.doi.org/10.4314/ahs.v18i2.32

32. Mushi MF, Ngeta N, Mirambo MM, Mshana SE. Letter to the editor 2: Predictors of oesophageal candidiasis in persons with or without HIV infection. Afri Health Sci. 2018;18(2): 470-471. https://dx.doi.org/10.4314/ahs. v18i2.33 